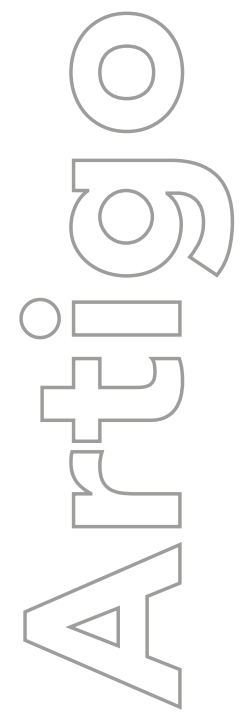

revista

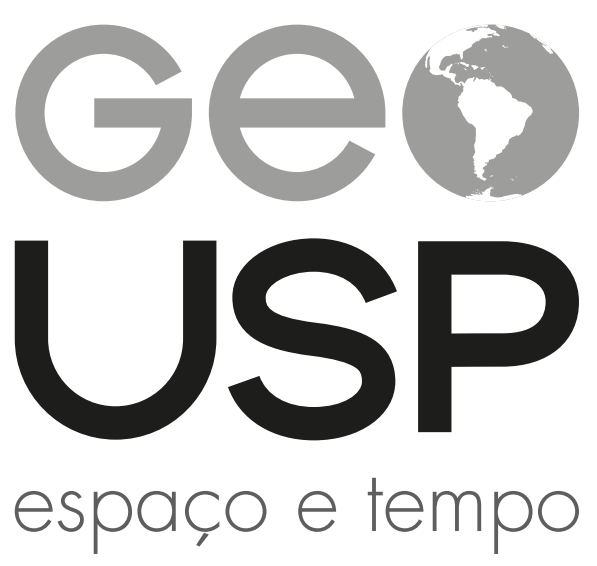

Volume $25 \cdot n^{\circ} 3$ (2021)

ISSN 2179-0892

\section{A difusão geográfica inicial da Covid-19 no Brasil e a aeromobilidade}

\section{Gabriel Teixeira Barros}

Universidade do Estado do Rio de Janeiro. Instituto de Geografia. Rio de Janeiro. Rio de Janeiro. Brasil gabriel.t.barros@gmail.com (1) 0000-0002-7099-5694

e-178541

Como citar este artigo:

BARROS, G. T. A difusão geográfica inicial da Covid-19 no Brasil e a aeromobilidade. Geousp, v. 25, n. 3, e-178541, dez. 2021. ISSN 2179-0892.

Disponível em: https://www.revistas.usp.br/geousp/article/view/178541. doi: https://doi.org/10.11606/issn.21790892.geousp.2021.178541.

\section{(c) (7)}

Este artigo está licenciado sob a Creative Commons Attribution 4.0 Licence 


\section{A difusão geográfica inicial da Covid-19 no Brasil e a aeromobilidade}

\section{Resumo}

Esse artigo investiga o fenômeno da difusão geográfica inicial da Covid-19 no Brasil, procurando contribuir com a formulação de políticas públicas para a contenção pandêmica. Para tanto, foi dividido em três partes: primeiramente, dados dos boletins epidemiológicos do Brasil, da Argentina e do Equador desde o início de sua divulgação até o dia 20/04/2020 foram transformados em mapas e analisados à luz de suas respectivas políticas de contenção, em comparação com China e Cingapura. Depois, em escala nacional, as analisam-se dados de 25/02/2020 a 03/08/2020, por município, comparados ao fluxo aéreo dominante de passageiros (IBGE, 2013). Na terceira parte, discute-se a relação entre a aeromobilidade e a modernidade líquida. Concluímos que uma suas primeiras ações de um protocolo de contenção pandêmica emergencial deveria ser o fechamento dos aeroportos, principalmente os de São Paulo, tanto para voos internacionais como nacionais, pois isso atrasaria consideravelmente a rede de difusão da doença.

Palavras-chave: Covid-19. Difusão geográfica. Políticas públicas. Rede de transportes. Aeromobilidade.

\section{Covid-19 early geographical spread and aeromobility in Brazil}

\section{Abstract}

This paper aims to investigate the Covid-19 geographical spread in Brazil, supporting future pandemic contention public policies. This article was divided into three parts: First, we organized data from the epidemiological reports from Brazil, Argentina and Ecuador, since the beginning of their publishing to Apr.20, 2020, then we plotted them into maps and analyzed taking into account their respective national disease control policies, also comparing with China and Singapore. After that, in a national scale, we analyzed the data, by County, from Feb.02, 2020, to Aug.03, 2020, comparing them with the dominant air-passenger flux (IBGE, 2013). In the third part, we approached the relationship between the 
aeromobility and the liquid modernity. We conclude that an emergency disease control protocol must have, as one of its first actions, the interdiction of airports, mainly those of São Paulo, to either national and international flights, in order to slowdown the disease spread network.

Keywords: Covid-19. Geographical spread. Public policies. Transport network. Aeromobility.

\section{La dispersión geográfica inicial del Covid-19 en Brasil y la aeromovilidad}

\section{Resumen}

Esta investigación busca investigar el fenómeno de la propagación geográfica del Covid-19 en Brasil. Este artículo fuera dividido en tres partes: primeramente, fueran organizados datos de los boletines epidemiológicos de Brasil, Argentina y Ecuador, desde el inicio de su difusión hasta el 20/04/2020, transformándolos en mapas y analizándolos por sus respectivas políticas de contención, en comparación con China e Singapur. Después, en escala nacional, los datos correspondientes al periodo del 25/02/2020 al 06/01/2020, por municipio, fueran comparados con el flujo dominante de pasajeros de aire (IBGE, 2013). En la tercera parte, abordamos la relación entre la aeromovilidad y la modernidad liquida. Así, pudimos concluir que un protocolo de contención pandémica de emergencia debe tener como una de sus primeras acciones el cierre de aeropuertos, principalmente los de São Paulo, tanto para vuelos internacionales como nacionales, ya que esto retrasaría considerablemente la red de propagación de la enfermedad.

Palabras clave: Covid-19. Difusión geográfica. Políticas públicas. Red de transporte. Aeromovilidad.

\section{Introdução}

Vivemos um momento conturbado da relativamente curta história da humanidade. A pandemia causada pelo vírus Sars-Cov2, doença denominada Covid-19, já matou milhões de pessoas em todo o mundo e uma vacina ainda é ansiosamente esperada por todos, que almejam uma volta ao "normal" e relutam amargamente em aceitar que, aquilo que vivemos agora, pode vir a se tornar o "novo normal". Ainda é cedo para dizer se essa pandemia terá, daqui em diante, um efeito catastrófico, mobilizador ou transformador da sociedade; se ficará 
marcada na história como a gripe espanhola (século XX) ou a peste bubônica (século XIV) ou irá perder-se, como os recentes vírus causadores de ebola, síndrome respiratória aguda grave (Sars) e síndrome respiratória do médio-oriente (Mers), já neste século.

Porém, apesar de todas as incertezas, a pandemia de Covid-19 nos permite, já neste momento, destacar um ponto a seu respeito: ela exacerbou uma série de problemas advindos do processo de globalização totalitária ou globalitária, como pontua Milton Santos (2000). Entre eles, a carência dos serviços públicos gratuitos de atendimento de saúde em países ultraneoliberais (Davis, 2020), como os EUA, versus os sistemas públicos de saúde, embora sucateados, dos países europeus, herdados do período de welfare state (Bihr, 2020; Badiou, 2020, p. 40); a importância da medicina preventiva e do acompanhamento contínuo das unidades básicas de saúde (o que em grande parte do Brasil era feito pelos médicos cubanos, que deixaram o país em 2018) (Cuba..., 2018); a guerra comercial pelas máscaras N-95, que levou os EUA a montar um esquema digno de ser chamado de contrabando, ao interceptar mercadorias já negociadas com outros países nas pistas de decolagem de Xangai ou retendo a carga aérea em seu território (Carga..., 2020) e, por fim, a corrida imunológica pela criação e distribuição da primeira vacina e, mais importante, de sua patente exclusiva (Oliveira, J., 2020).

Ainda entre Estados-nação, exacerbou-se o debate político e o contraste entre a crescente nova ultradireita de base fascista e neonazista e sua preferência pela preservação do circuito econômico de acumulação e reprodução do capital, contra os outros, que ainda consideram a relevância de uma vida humana. Isso se refletiu tanto nas políticas de contenção de disseminação do vírus adotadas pelo poder público - quarentena, isolamento e distanciamento social - quanto na adesão da população a essas políticas, o que resultou em índices de contágio muito díspares entre países bem próximos, como o próprio Brasil e a Argentina ou o Paraguai, e "sintomaticamente melhores nos países menos neoliberais como: China, Coreia do Sul, Taiwan e Cingapura" (Harvey, 2020, p. 18).

Na rede de transportes, as disparidades socioeconômicas foram notórias, principalmente em dois momentos: primeiro, na chegada do vírus aos países ocidentais, que se deu principalmente pelo transporte aéreo, por meio da população de maior poder aquisitivo, e, num segundo momento, pelas altas taxas de contágio entre a população mais pobre, que, impedida de praticar a quarentena pela necessidade de manter a renda, não pôde abrir mão do transporte público, que continuou lotado apesar de todas as restrições (Harvey, 2020, p. 21). Com a queda de parte da demanda de passageiros, as empresas diminuíram também a oferta de serviços, mantendo o alto nível de ocupação das composições de praticamente todos os modais, como por exemplo a concessionária de transporte ferroviário SuperVia, no Rio de Janeiro (Moreira, 2020).

Não se sabe ainda a origem do vírus, e isso só seria possível pelo mapeamento de seu genoma e dos diferentes clados vigentes, como indica a plataforma de dados de Hadfield et al. (2018), que identifica os principais clados de Sars-Cov2 presentes nos principais países do mundo e o de Candido et al. (2020), que o faz para o Brasil. A partir desses dados, que devemos ressaltar não serem conclusivos por conta da baixa amostragem, poderíamos inferir que há uma grande probabilidade que, da China, ele tenha chegado à Itália e aos EUA, e assim ao Brasil, por essas duas vertentes distintas. Candido et al. (2020), em um estudo massivo de análise genômica 
de 427 amostras coletadas no Brasil entre 5 de março e 30 de abril de 2020, apontam ao menos 102 amostras genômicas com origem internacional e confirmam essa impressão inicial. De 266 amostras sequenciadas, 28\% puderam ser associadas à Itália e 28\% aos EUA. A plataforma de Hadfield et al. (2018) mostra que os genomas virais de Sars-Cov2 que mais circulam no Brasil são os clados A2a (assim como a maior parte da Europa) e Ala, e em menor quantidade o clado B, que é mais comum nos países orientais (Hadfield et al., 2018).

Outro fato importante é que a origem do vírus, supostamente em Wuhan, na China, pode ter sido provocada pela constante devastação das florestas e degradação do ambiente, que colocam cada vez mais em contato próximo a fauna silvestre e a sociedade urbana, além das condições de salubridade encontradas no mercado municipal de Wuhan, onde muitos animais silvestres eram mantidos vivos em condições precárias junto aos mercadores e compradores (Badiou, 2020, p. 37). Porém, apesar de se saber que o vírus é uma recombinação do coronavírus de morcegos e cobras, uma hipótese é que ele tenha habitado um hospedeiro intermediário, como um pangolim, e não é possivel afirmar que ele tenha surgido no mercado de Wuhan (Kuguyo, Kengne; Dandara, 2020).

Em termos de sua disseminação, não há dúvida que, em escala intercontinental, o transporte aéreo foi o vetor de destaque na disseminação viral. No Brasil, a principal conexão com a rede urbana mundial se dá por meio da Metrópole de São Paulo, que concentra os principais fluxos aéreos de destino de toda a rede dominante do país (IBGE, 2013), como é possível observar no Mapa 1. De acordo com Candido et al. (2020), no início de março de 2020, a transmissão local já estava em curso no país, e, mesmo após a implantação das medidas de proteção não farmacológicas, as viagens nacionais de longa distância ( $>2.000 \mathrm{~km}$ ) foram menos afetadas que as de curta distância $(<1.000 \mathrm{~km})$, comparados os períodos entre 1 e 21 de março de 2020 e entre 21 de março e 15 de abril de 2020:

Essas descobertas dão ênfase ao papel da mobilidade intraestadual e interestadual como um vetor chave tanto da disseminação local como inter-regional do vírus, com as conurbações densamente povoadas e fortemente conectadas da região Sudeste atuando como principal fontes de exportação do vírus dentro do país (Candido et al., 2020, p. 5). ${ }^{2}$

Portanto, pretendo fazer aqui uma pesquisa exploratória e qualitativa com o objetivo de contribuir com a construção de conhecimento sobre o fenômeno da difusão geográfica da Covid-19 em escala nacional, por meio da análise da relação entre as notificações de casos disponibilizadas pelas Secretarias Estaduais de Saúde e os fluxos aéreos dominantes no Brasil, identificados pelo Instituto Brasileiro de Geografia e Estatística (IBGE) em 2010 e publicado em 2013, a fim de ajudar na formulação de futuras políticas públicas para contenção pandêmica.

1 Em recente estudo publicado pela Organização Mundial da Saúde (OMS, 2021, p. 47), que investigou as supostas origens do vírus na China por meio da distribuição geográfica dos casos, não foi possível afirmar que ele tenha provindo do mercado de Huanan (Hubei, Wuhan). Também foram detectados casos em torno de outros mercados locais, além de casos sem associação direta com nenhum mercado. $\bigcirc$ mesmo relatório aponta que, entre setembro e dezembro de 2019, houve 44 grandes eventos em Wuhan, com um total de 69.966 participantes, dos quais 11.511 eram estrangeiros. Entre os eventos, constam a $7^{\text {a }}$ Olimpíada Militar (9.308 participantes) e o World Bridge Team Championships (OMS, 2021, p. 29).

2 "These findings emphasize the roles of within- and between-state mobility as a key driver of both local and interregional virus spread, with highly populated and well-connected urban conurbations in the southeast region acting as the main sources of virus exports within the country" (Candido et al. 2020, p. 5). 
Mapa 1 - Fluxo dominante de passageiros por meio aéreo no Brasil em 2010

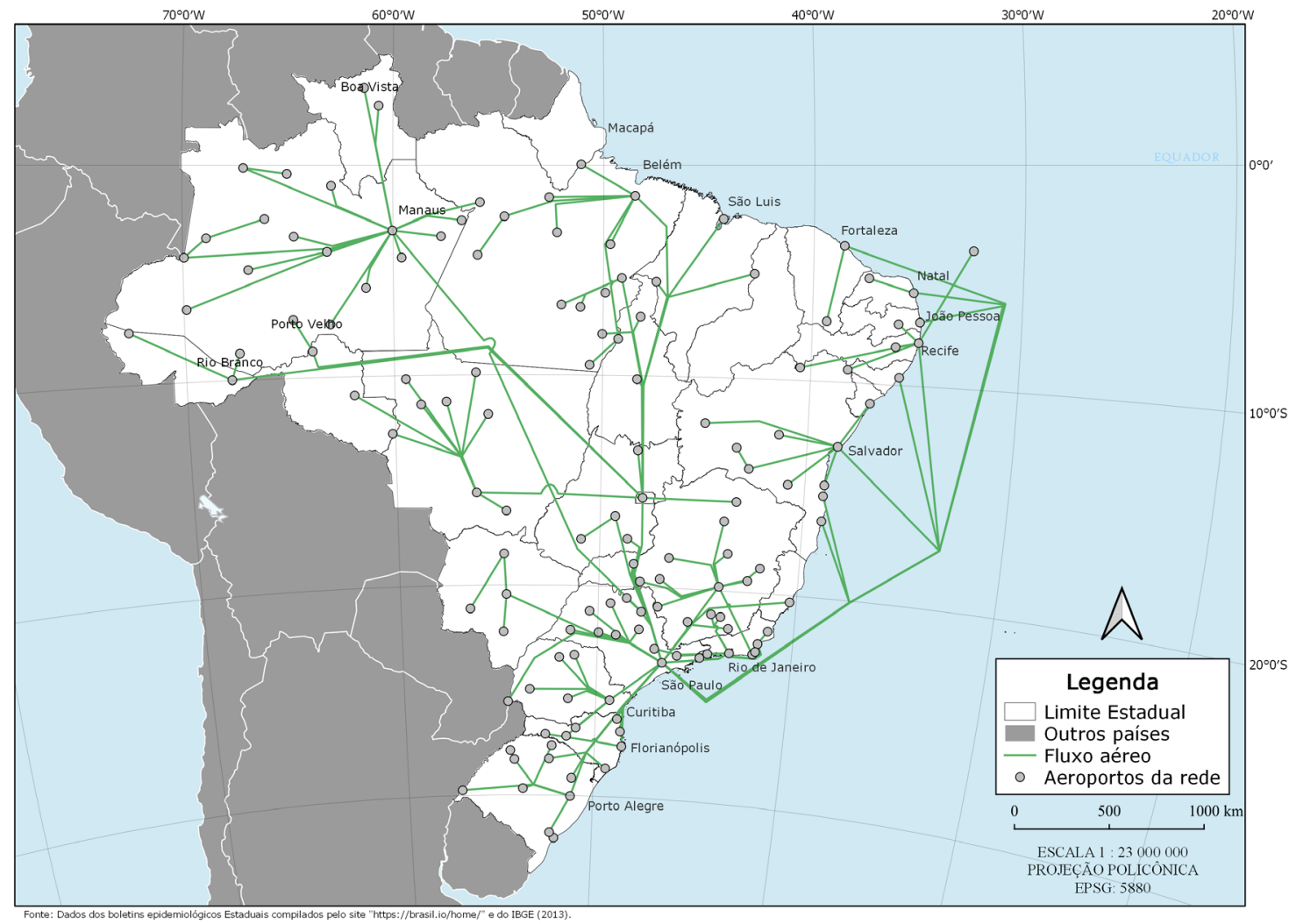

fonte: $\bigcirc$ autor, 2020. Adaptado de IBGE (2013).

Mapa 2 - Voos internacionais para o Brasil no 10 trimestre de 2020

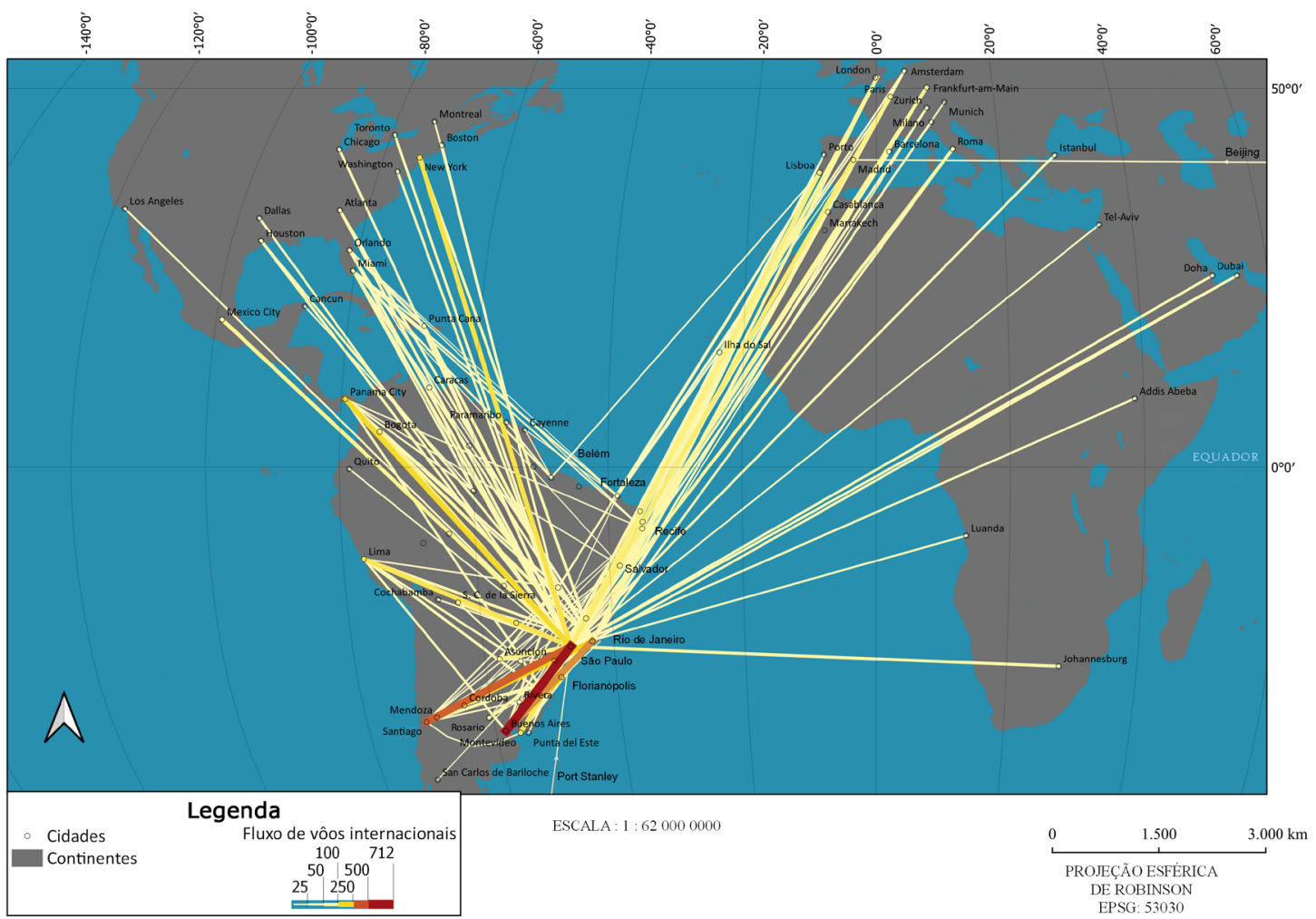

fonte: $\bigcirc$ autor, com dados da Anac, 2020. 
No Mapa 2, elaborado com dados da Agência Nacional de Aviação Civil (Anac), é possível verificar a forte centralidade da região Sudeste em escala nacional, concentrando a maior parte dos voos internacionais para o Brasil. Do total de voos internacionais com destino a São Paulo (4.910), $51,61 \%$ provinham de capitais latino-americanas, enquanto $21,02 \%$ vieram da Europa e 17,98\% dos EUA ou do Canadá. $\bigcirc$ Rio de Janeiro recebeu 53,21\% de seu total de voos internacionais (1.898) de capitais latino-americanas, enquanto 23,23\% da Europa e 11,85\% de EUA e Canadá. Em Manaus, EUA e Canadá foram responsáveis por 41,24\% do total de voos internacionais recebidos no período (97), enquanto 37,11\% foram de capitais latino-americanas e 21,65\% de outras cidades latino-americanas. Em Belo Horizonte, que teve um total de 135 voos internacionais, 47,41\% foram provenientes de capitais latino-americanas, enquanto 28,15\% da Europa e 24,44\% de EUA e Canadá.

No 10 trimestre, 15 voos provieram da China, de Pequim, com destino a São Paulo e escala em Madri. ${ }^{3}$ Dos EUA, foram feitas conexões da Flórida a Brasília e a algumas das principais capitais do Nordeste, enquanto Nova York e outras cidades do norte têm conexão prioritária com São Paulo. Outras conexões foram realizadas com Adis Abeba, Johanesburgo e Dubai, sendo esta última um importante hub de distribuição de voos internacionais. A lista das linhas com o maior número de voos no $1 \circ$ trimestre de 2020 está no Quadro 1.

\section{Quadro 1 - Número de voos internacionais para o Brasil, por origem e destino, no 10 trimestre de 2020, limitado a 22 linhas}

\begin{tabular}{|c|c|c|c|}
\hline $\mathbf{n}^{\circ}$ & cidade de origem & cidade de destino & voos (un) \\
\hline 1 & Buenos Aires & São Paulo & 718 \\
\hline 2 & Santiago & São Paulo & 481 \\
\hline 3 & Buenos Aires & Rio de Janeiro & 235 \\
\hline 4 & Santiago & Rio de Janeiro & 265 \\
\hline 5 & Buenos Aires & Florianópolis & 241 \\
\hline 6 & Cidade do Panamá & São Paulo & 211 \\
\hline 7 & Nova York & São Paulo & 198 \\
\hline 8 & Lima & São Paulo & 194 \\
\hline 9 & Miami & São Paulo & 194 \\
\hline 10 & Montevidéu & São Paulo & 172 \\
\hline 11 & Madri Paulo & 160 \\
\hline 12 & Lisboa & São Paulo & 153 \\
\hline 13 & Paris & São Paulo & 152 \\
\hline 14 & Assunção & São Paulo & 150 \\
\hline 15 & Bogotá & São Paulo & 134 \\
\hline 16 & Cidade do México & São Paulo & 117 \\
\hline 17 & Santa Cruz de la Sierra & São Paulo & 114 \\
\hline 18 & Londres & São Paulo & 111 \\
\hline 19 & Frankfurt-am-Main & São Paulo & 109 \\
\hline 20 & Buenos Aires & Campinas & 98 \\
\hline 21 & Cidade do Panamá & Rio de Janeiro & 96 \\
\hline 22 & Buenos Aires & Curitiba & \\
\hline
\end{tabular}

fonte: $O$ autor, com dados da Anac, 2020.

3 Lembrando que existem outras conexões indiretas da China para o Brasil. 
Assim, é impossível estabelecer a origem da doença por meio desse tipo de levantamento, visto que, por conta da globalização e do encurtamento do espaço-tempo ensejado pelos avanços tecnológicos da aviação, seria plausível que, em menos de 24 horas, o paciente-zero tivesse ido de qualquer lugar a qualquer outro do globo. Uma pesquisa nesse sentido deveria verificar o número de conexões que as principais cidades internacionais que têm fluxo aéreo com o Brasil realizam com outros países, como a Argentina (Buenos Aires) e o Chile (Santiago).

\section{Políticas públicas de contenção pandêmica}

Devemos, primeiramente, fazer uma distinção entre política pública, programa, ação e protocolo. Para Celina Souza (2006, p. 26), "a formulação de políticas públicas constitui-se no estágio em que os governos democráticos traduzem seus propósitos e plataformas eleitorais em programas e ações, que produzirão resultados ou mudanças no mundo real". A partir dessa afirmação, podemos entender que a política pública é mais abrangente do que os programas e as ações, além de ter maior temporalidade. Mas podemos distinguir entre políticas públicas de governo e de Estado, que seriam aquelas que prevaleceriam independentemente do governo, como é o caso de leis promulgadas. Os programas são sempre de governo e têm um grau intermediário de abrangência, podendo um programa conter diversas ações em seu bojo. As ações, portanto, são o grau primário de ação governamental e, quando não estão inseridas num programa, são chamadas de ações pontuais ou isoladas. Já os protocolos podem ser definidos como processos predefinidos, um conjunto de ações coordenadas e encadeadas a partir de um evento específico pontual ou recorrente, como por exemplo os protocolos de segurança ou de diplomacia.

Entender os mecanismos de disseminação da doença é essencial se quisermos evitar futuras pandemias ou epidemias como essa. De fato, mais do que características determinantes do ambiente vivido ou da paisagem urbana, as políticas públicas adotadas pelos governos e o timing das ações são também fatores de contenção ou aceleração da disseminação. Países que adotaram o lockdown logo que descobriram os primeiros casos de Covid-19, como a Argentina, tiveram resultados mais brandos de contaminação num primeiro momento, o que possivelmente evitou muitas mortes ditas evitáveis - aquelas que decorrem de falta de condições de tratamento.

A seguir, comparamos a disseminação dos casos de Covid-19 na Argentina, no Equador e no Brasil.

\section{Quadro 2 - Datas importantes de contaminação e enfrentamento da disseminação de Covid-19 em algumas unidades territoriais durante os primeiros meses de disseminação}

\begin{tabular}{|l|c|c|c|}
\hline \multicolumn{1}{|c|}{ unidade territorial } & 1 ' caso confirmado & $\begin{array}{c}\text { lockdown } \\
\text { (mais severo) }\end{array}$ & $\begin{array}{c}\text { isolamento parcial } \\
\text { (mais brando) }\end{array}$ \\
\hline Brasil & $25 / 02 / 2020$ & não decretou & - \\
\hline Pará & $18 / 03 / 2020$ & $07 / 05 / 2020$ & - \\
\hline Maranhão & $20 / 03 / 2020$ & $30 / 04 / 2020$ & - \\
\hline Amapá & $20 / 03 / 2020$ & $19 / 05 / 2020$ & - \\
\hline Fortaleza (CE) & $15 / 03 / 2020$ & $08 / 05 / 2020$ & - \\
\hline
\end{tabular}




\begin{tabular}{|l|c|c|c|}
\hline \multicolumn{1}{|c|}{ unidade territorial } & 10 caso confirmado & $\begin{array}{c}\text { lockdown } \\
\text { (mais severo) }\end{array}$ & $\begin{array}{c}\text { isolamento parcial } \\
\text { (mais brando) }\end{array}$ \\
\hline Niterói (RJ) & $09 / 03 / 2020$ & $11 / 05 / 2020$ & - \\
\hline São Gonçalo (RJ) & $23 / 03 / 2020$ & $11 / 05 / 2020$ & - \\
\hline São Paulo & $25 / 02 / 2020$ & não decretou & $22 / 03 / 2020$ \\
\hline Rio de Janeiro & $05 / 03 / 2020$ & não decretou & $16 / 03 / 2020$ \\
\hline Argentina & $05 / 03 / 2020$ & $20 / 03 / 2020$ & - \\
\hline Equador & $29 / 02 / 2020$ & $18 / 03 / 2020$ & - \\
\hline
\end{tabular}

fonte: $O$ autor, com base em Gl (Dória..., 2020), UOL (Oliveira, M.; Mello, 2020), Estado de Minas (Argentina..., 2020), R7 (Equador..., 2020) e BBC (Smink, 2020; Jones, 2020).

No Quadro 2, diferenciamos o lockdown do isolamento parcial por meio das notícias examinadas. $O$ primeiro incluiu declaração de emergência ou toque de recolher (como decretado no Equador), fechamento do comércio e de estabelecimentos e restrição de circulação nas ruas em toda a área da cidade (no Rio de Janeiro, essa medida só foi adotada em partes da cidade). Já o segundo, denominado isolamento parcial, foi considerado mais brando, pois apenas parte da população e do território sofreram restrição de mobilidade.

Argentina e Equador decretaram medidas de isolamento mais severas já em março, tendo a Argentina o feito só 15 dias após a confirmação do primeiro caso, enquanto o Equador o fez depois de 19 dias. No Brasil, não houve uma iniciativa unificada por parte do governo federal de incentivar medidas de isolamento, tendo estas ficado totalmente a cargo dos estados, que só começaram a tomá-las em 30/04/2020, no Maranhão, mais de dois meses após a primeira notificação da doença. Os efeitos dessas ações podem ser observados no Mapa 3. Os dados dos outros países, por província, foram coletados pelo autor, com base nos boletins epidemiológicos disponibilizados pelos ministérios da Saúde desses países.

Até 20/04/2020, é possível observar como a doença aparece na província de Guayas, no Equador, e permanece fortemente concentrada aí e em Pichincha, pouco mais ao norte. O ritmo de evolução de casos em Guayas é semelhante ao do estado de São Paulo, exceto na última semana investigada (de 13/04 a 20/04), quando São Paulo passa a faixa de 10 mil mortes. Na Argentina, o número de casos tem uma evolução bem mais lenta, ficando a maior parte concentrada na Província de Buenos Aires e na Cidade Autônoma.

No Brasil, é possível identificar mais de um foco de grande evolução do número de casos, notadamente São Paulo, Rio de Janeiro, Ceará, Amazonas e Pernambuco. É importante notar como diversos estados caminham num ritmo semelhante de evolução de casos, tendo um ápice na semana de 12 a 20 de abril, quando um grande número de estados no litoral passa a faixa de mil contaminados confirmados.

Existem no mapa duas discrepâncias que a divisão territorial dos países esconde e que precisam ser ressaltadas: a contagem de casos na Cidade Autônoma de Buenos Aires é separada da Província de Buenos Aires, da mesma forma que o Distrito Federal está separado de Goiás, com uma grande discrepância de área territorial. Com isso, se somarmos os casos de ambos os distritos a seus estados vizinhos para equalizar essas diferenças, notaremos que a evolução da doença em Buenos Aires (cidade mais província) foi semelhante à do estado de São Paulo e à de Brasilia mais Goiás. 
Ainda para equalizar as diferenças de tamanho entre as unidades territoriais, podemos afirmar que a evolução do número de casos confirmados foi mais severa no Equador, visto que suas províncias são muito menores em área do que as de Argentina ou dos estados do Brasil, e muito menores em população do que Buenos Aires, Rio de Janeiro e São Paulo. A principal diferença entre esses países, em termos de difusão da contaminação, reside no fato de que, enquanto no Equador e na Argentina o foco de descontrole ficou restrito às províncias capitais (Guayas e Buenos Aires mais Cidade Autônoma), no Brasil, verificam-se ao menos três focos regionais de contaminação mais alta: Rio de Janeiro mais São Paulo, Amazonas e Ceará.

\section{Mapa 3 - Evolução dos casos confirmados de Covid-19 na América do Sul, comparando Brasil, Argentina e Equador, de 16 de março a 20 de abril de 2020}
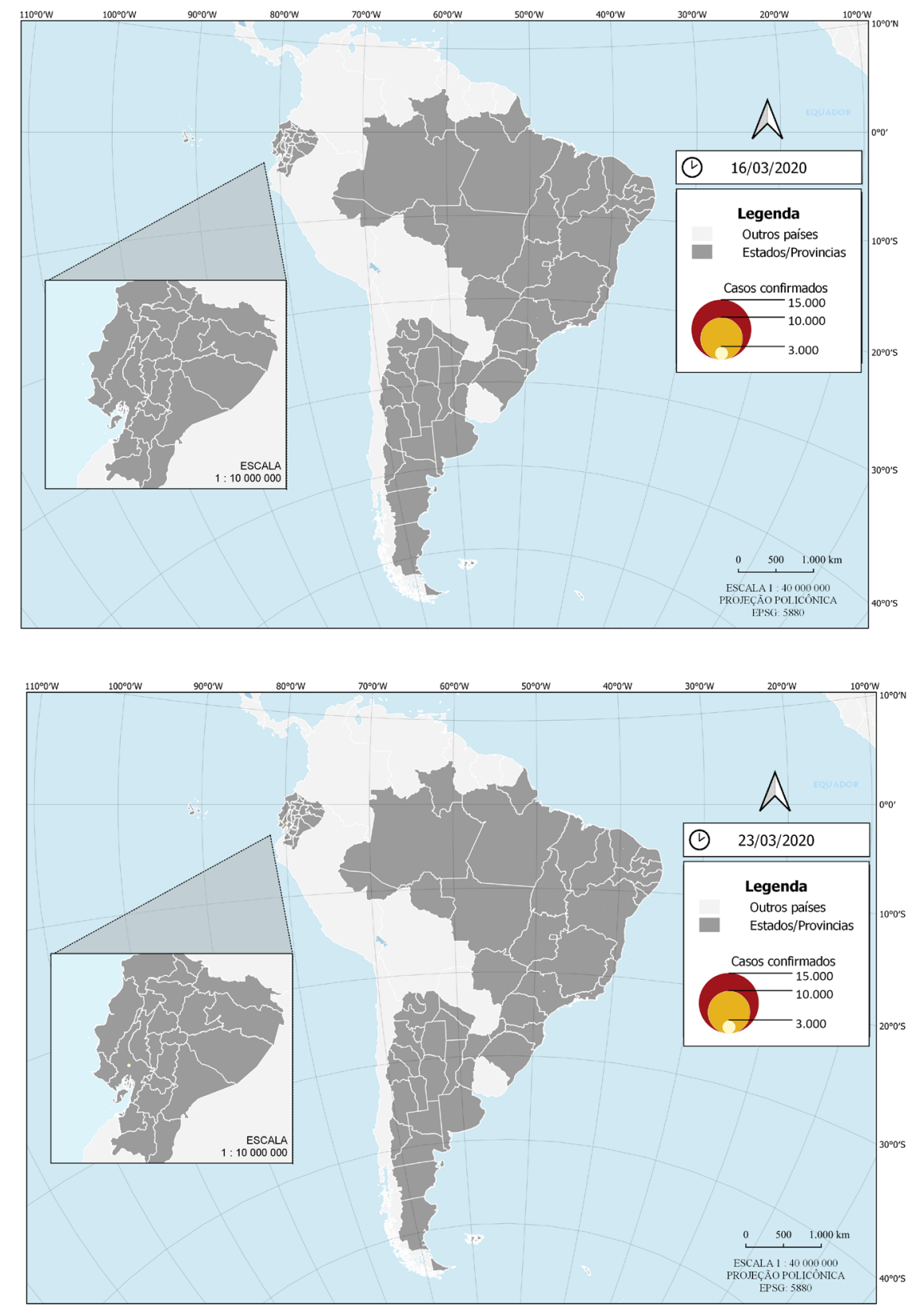




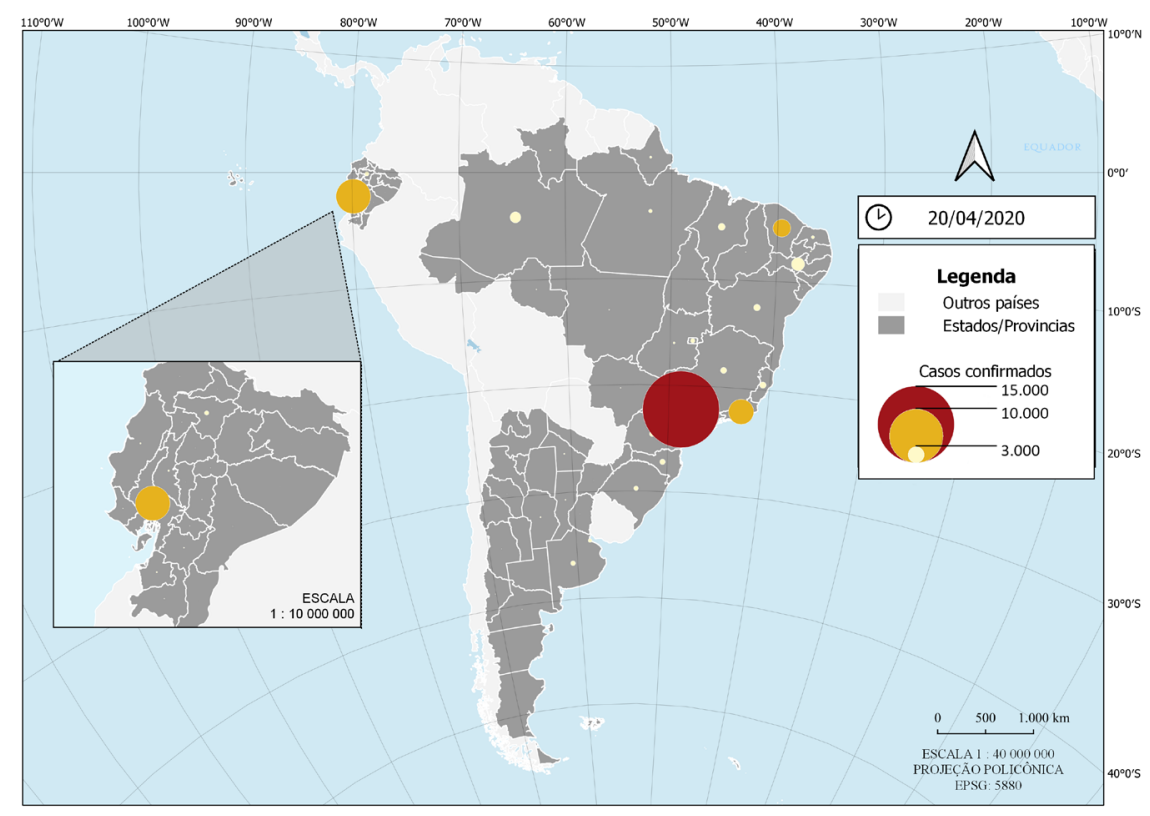

fonte: $\bigcirc$ autor, com dados dos boletins epidemiológicos desses países e, no Brasil, com dados do Brasil.IO (2020).

Para fazer uma comparação com países que adotaram outras políticas de contenção, recorremos aos países asiáticos. Um bom exemplo de políticas de contenção pandêmica foi oferecido por Cingapura, onde, segundo a BBC (Jones, 2020), já havia protocolos de contenção antes mesmo de a Covid-19 receber sua denominação oficial. $\bigcirc$ país lidou com a doença em seu início fazendo "controle sanitário nos aeroportos, testes exaustivos em cada caso suspeito", "localizou qualquer pessoa que tivesse entrado em contato com um caso confirmado e confinou esses contatos em suas casas". Muito dessa prevenção se deve ao fato de o país ter lidado com o grave surto de Sars em 2001, que foi crucial na geração de diversos protocolos sanitários e de prevenção. Essa consequência da Sars no Oriente, que não teve o mesmo peso no Ocidente, fica evidente na fala de Nis Grünberg, do Instituto Mercator de Estudos da China, em Berlim, à emissora alemã Deutsch Welle (Martin, 2020), porém se referindo ao governo de Pequim: "a má gestão do surto de Sars é claramente um fantasma que o governo teme, e as próximas semanas mostrarão o quanto de aprendizado em gestão e mecanismos de resposta a crises surgiu desde a epidemia de 2003".

Segundo Kuguyo, Kegne e Dandara (2020, p. 471), Cingapura registrou seu primeiro caso da doença em 23/01/2020, mesma data que os EUA, e seria o país mais suscetível a receber um hospedeiro do vírus fora da China, visto que cerca de 3,4 milhões de pessoas viajam da China para lá anualmente. Porém a evolução da doença em Cingapura tem sido a mais lenta do mundo, com uma média de mortes também surpreendentemente mais baixa que a de outros países.

Ainda segundo os autores, uma das lições aprendidas pelo país após a epidemia de Sars em 2001 foi a instauração de 900 clínicas de saúde pública de resposta rápida (PHPC, na sigla em inglês), especializadas em avaliar pacientes com sintomas gripais ou pneumonia e classificando-os segundo o risco de contaminação. Nessas clínicas, após a classificação, os pacientes com alto risco são encaminhados a um hospital também especializado e passam 
a ser monitorados. Em contraponto a essa política pública continuada de contenção e de Cingapura, está a política de contenção emergencial da China, que a levou a construir um hospital com mil leitos em apenas seis dias.

Em ambos os países, porém, o isolamento das regiões epidêmicas foi essencial para conter a disseminação, o que incluiu fechamento de portos e aeroportos, checagem de temperatura e testagem em massa, seguida de monitoramento. Cingapura tem uma das mais altas taxas de testagem por milhão de pessoas no mundo, mais até do que países como os EUA, o Canadá ou a Alemanha (Kuguyo; Kegne; Dandara, 2020).

Esse tipo de comparação nos leva a crer que, na verdade, muito da morosa e ineficiente resposta dos países ocidentais ao novo coronavírus e da falta de mecanismos de contenção e políticas públicas conjuntas ocorreram por conta de um pensamento colonialista e ocidentalista, que ignorou completamente as últimas epidemias, pois acometeram em maior grau justamente os países do leste e do sudeste asiático (Sars), os países do Oriente Médio (Mers) e a África (ebola), despertando pouco interesse da comunidade política ocidental.

Por meio da Figura 1, é possível ver bem os efeitos gerados pelas diferentes ações e políticas adotadas pelos países citados. A política de contenção emergencial na China perfez uma curva de rápido crescimento no início, porém que rapidamente se estabilizou na faixa de 80 mil casos e nessa faixa seguiu até o momento. Em Cingapura, a política de atenção primária contínua das PHPC gerou uma curva amena, que resistiu até abril de 2020 antes de iniciar sua subida e estabilizou suavemente na faixa de 55 mil casos. Já no Brasil e na Argentina, o número de contaminados em relação à China vem sendo mais do que 60 vezes superior, sendo que a população total desse país é seis vezes maior que a do Brasil (estimadas hoje, respectivamente, em 1,4 bilhões contra 210 milhões de pessoas). Outro detalhe é que a curva referente aos países americanos citados não parece ter-se estabilizado, apresentando-se ainda acentuada, enquanto é perceptível que na Argentina a curva faz uma ascensão mais côncava e tardia do que no Brasil, cuja curva é claramente linear. Esse movimento indica que, a partir de junho de 2020, houve uma mudança na dinâmica de propagação na Argentina, que provocou uma alteração na curva de casos, enquanto no Brasil a dinâmica se mantém a mesma desde maio de 2020.

Segundo o ex-ministro da Saúde, o argentino Adolfo Rubinstein (Carmo, 2020), a quarentena na Argentina "foi muito longa e na prática deixou de ser respeitada dois ou três meses depois do seu início", o que coincide justamente com o mês de junho de 2020. Para Omar Sued, presidente da Sociedade Argentina de Infectologia, "até pouco tempo atrás, praticamente não havia casos da doença no interior. Mas a reabertura no início de setembro foi feita sem os mesmos protocolos de prevenção contra o vírus que foram aplicados na Cidade Autônoma de Buenos Aires, a capital do país, e na Província de Buenos Aires" (Carmo, 2020). Ainda, ressalta-se que, assim como no Brasil, a Argentina tem altas taxas de informalidade ocupacional, o que gera insegurança financeira para as famílias e dificulta o isolamento. 
Figura 1 - Curvas do número total de casos confirmados de Covid-19 no Brasil, na Argentina, na China e em Cingapura de 15 de fevereiro a 23 de novembro de 2020
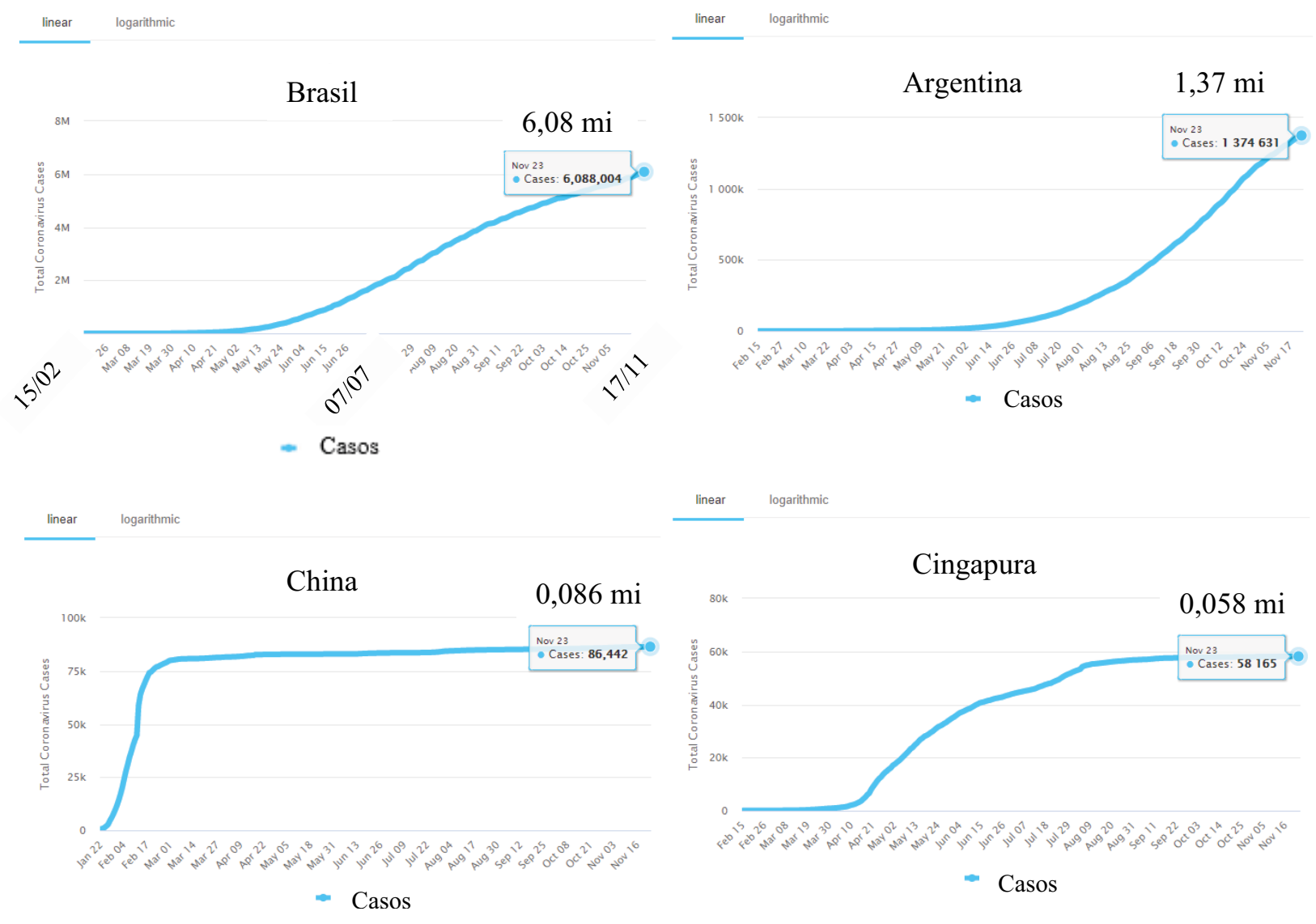

legenda: O eixo X é uma escala temporal que vai de 15 de fevereiro a 16/17 de novembro, e o eixo Y é o número de casos em escala relativa: Brasil e Argentina em milhões e China e Cingapura em dezenas de milhares.

fonte: Worldometer (2020).

\section{O início da difusão dos casos de Covid-19: fevereiro a agosto de 2020}

Desde a aparição do primeiro caso do novo coronavírus Sars-Cov2 no Brasil, por volta de fevereiro, a doença vem se dispersando por todo o país, deixando milhares de mortos. O Mapa 4 é resultado de um esforço científico para visualizar essa difusão geográfica e auxiliar na busca e construção de um melhor enfrentamento do fenômeno.

Os mapas foram elaborados com base nos números de casos confirmados por município, coletados pelas Secretarias de Saúde estaduais, compilados e disponibilizados pela equipe do site colaborativo Brasil.IO. Os mapas base utilizados foram os arquivos vetoriais oficias do IBGE para os 5.572 municípios do Brasil e os limites estaduais atualizados em 2018 na divisão territorial brasileira. Para a compilação dos dados geoespaciais foi utilizado o software QGIS 3.1. A projeção escolhida foi a policônica com meridiano de referência em 54० e datum SIRGAS 2000, de acordo com as normas vigentes do Sistema Brasileiro de Cartografia (IBGE, 2019). Essa forma de representação cartográfica privilegia a visualização dos dados no território brasileiro e pode ser encontrada pelo código EPSG: $5880 .{ }^{4}$

4 EPSG é a sigla para European Petroleum Survey Group. 
A frequência de plotagem dos dados foi definida como semanal a partir do dia 02/03/2020 (segunda-feira) para se manter a comparabilidade temporal entre os mapas, tendo sido o primeiro caso no Brasil confirmado em 25/02/2020. A série temporal vai até a data de 03/08/2020, quando se verifica a primeira estabilização contundente do aumento do número de casos. Essa data foi definida pela intenção desta pesquisa de pesquisar o fenômeno da difusão geográfica da doença, apenas em sua fase inicial. Metodologicamente, optou-se por utilizar os dados absolutos em vez de dados relativos por dez mil habitantes, como em Costa, E. e Costa, N. (2020), pois os primeiros nos permitem observar a evolução da doença e ao mesmo tempo não perder de vista a centralidade das grandes metrópoles, visto que o número de infectados cresce exponencialmente nesses locais.

\section{Mapa 4 - Casos confirmados de Covid-19 no Brasil, por município, de 23 de março a 3 de agosto de 2020}
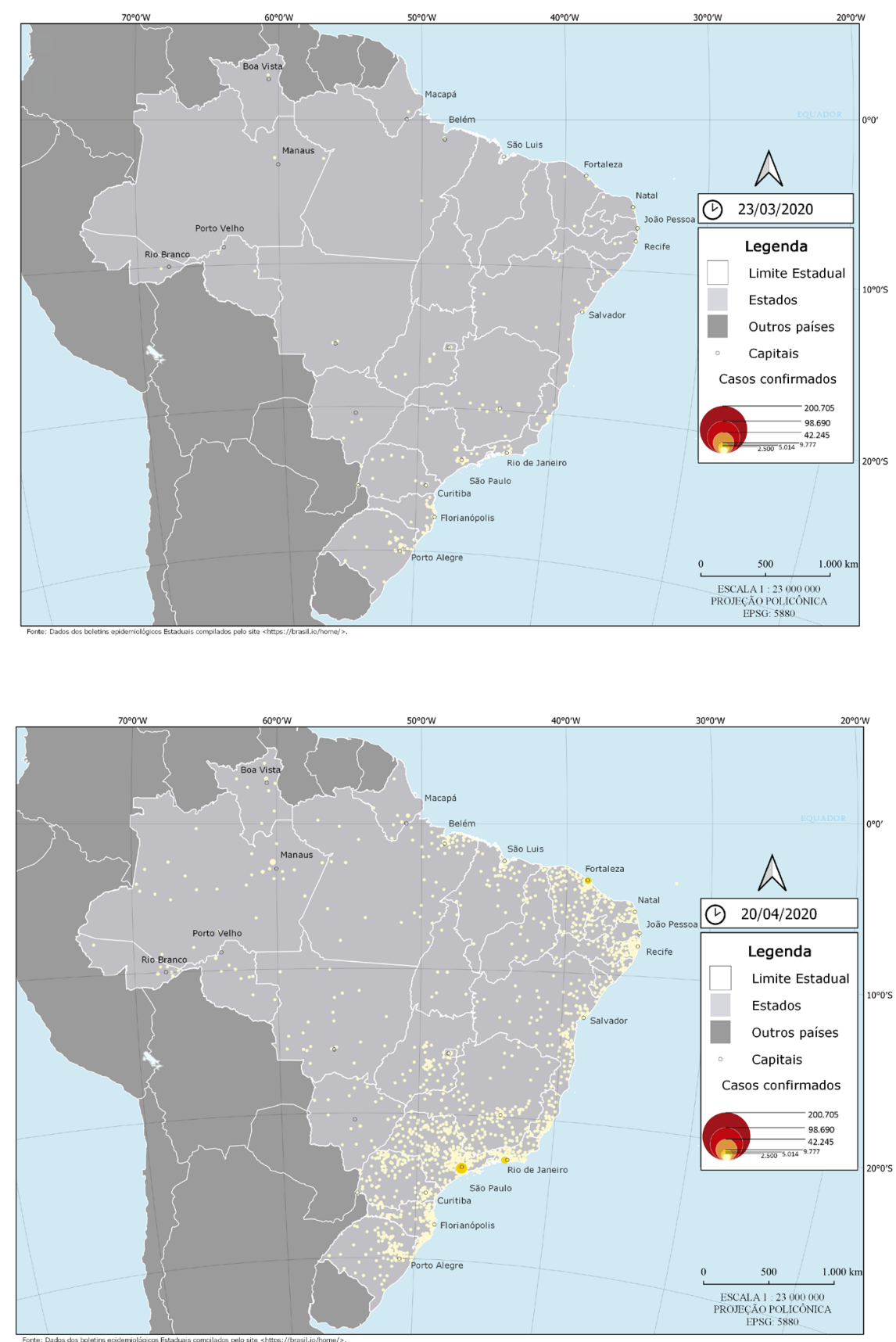

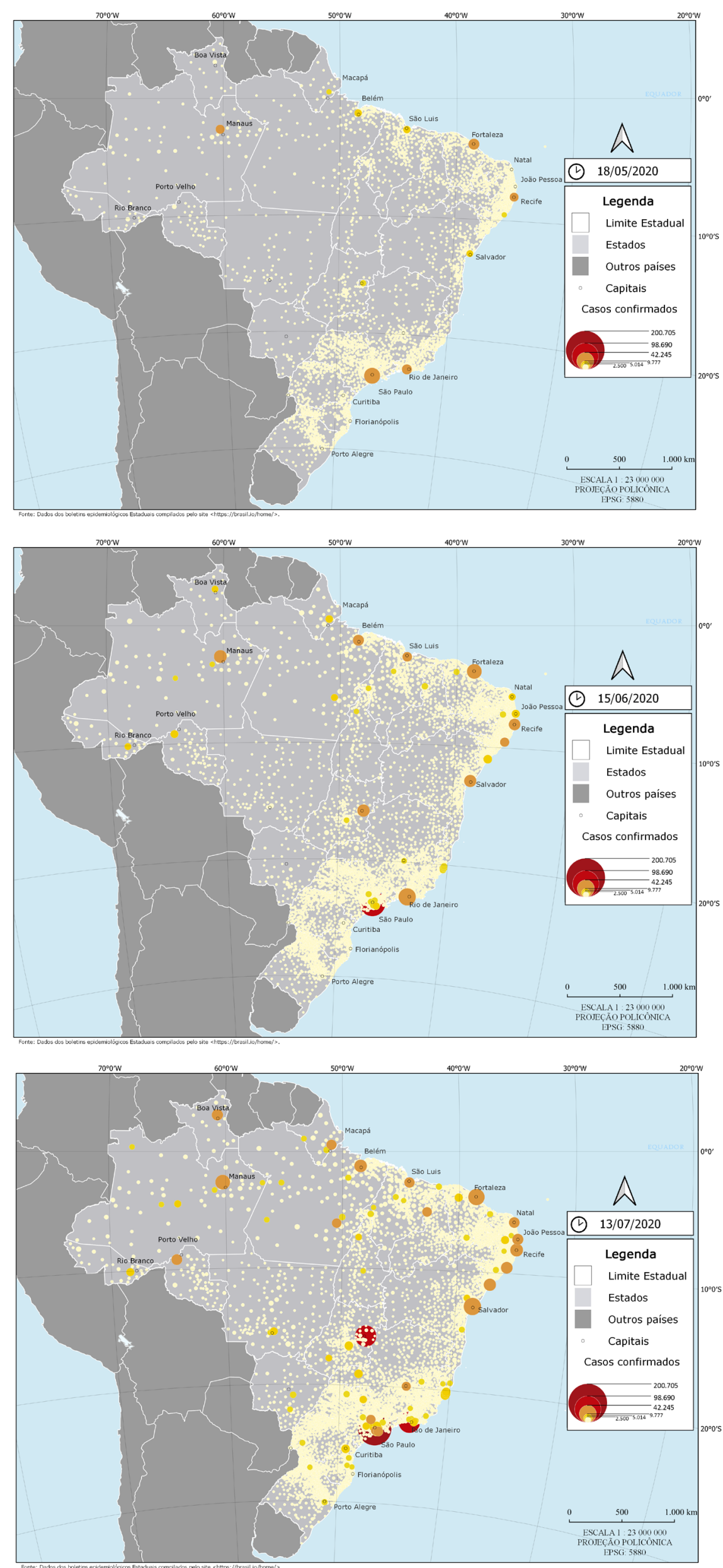


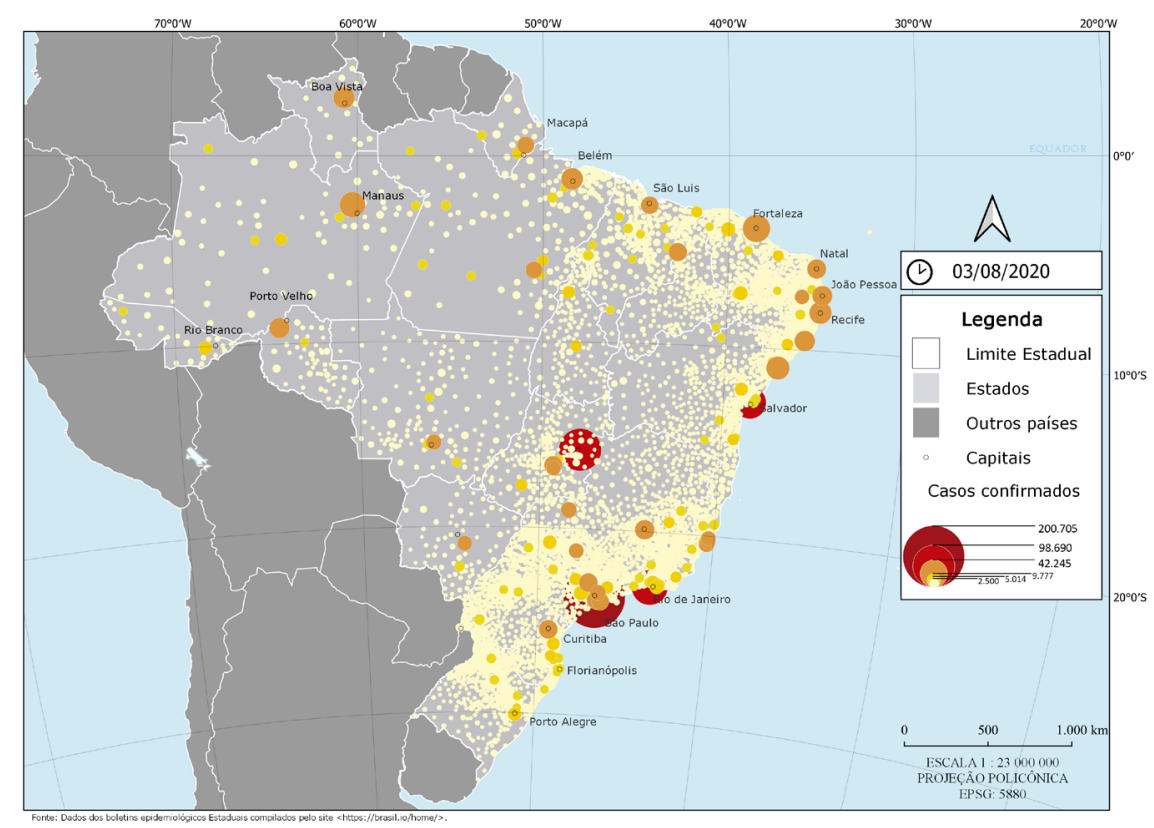

fonte: $\bigcirc$ autor, 2020, com dados de Brasil.IO (2020).

É interessante destacar como a doença se dissemina para o interior no estado do Ceará (principalmente), Maranhão e Pernambuco mais rapidamente que em outros estados do Nordeste, por causas que devem ser pesquisadas em escala mais ampla futuramente. No estado de São Paulo, também é possível notar essa rápida interiorização dos casos.

Segundo Candido et al. (2020), entre 1 e 21 de março, a disseminação viral foi mais contundente dentro das fronteiras estaduais, sendo quatro focos principais no Brasil: São Paulo, Rio de Janeiro, Minas Gerais e Ceará. Já o período entre 21 de março e 15 de abril se caracterizou pelo avanço dos casos em outros estados a partir da região Sudeste, imediatamente após a implementação de medidas de proteção não farmacológicas, como o fechamento de escolas e mercados.

\section{Aeromobilidade e modernidade líquida}

A disseminação da Covid-19 no mundo também pode ser vista por outra perspectiva bem atual nas ciências: a da mobilidade. Na atual modernidade tardia, pós-modernidade, ou modernidade líquida, como delineia Bauman (1998), a mobilidade dos indivíduos está em igualdade com o poder e o dinheiro. Quem tem mais poder financeiro tem mais mobilidade e mais facilidade para vencer distâncias espaço-temporais. Na rede de transporte aéreo, isso fica bem evidente quando comparamos os preços das passagens por número de escalas. Quem paga mais caro consegue comprar um voo direto, sem escalas, e com isso chegar mais depressa a seu destino. Essa é a tão falada supressão do espaço pelo tempo, conclamada por Harvey (2011) e já indicada por Marx. Essa abordagem expõe o caráter de injustiça socioespacial causado pelas engrenagens de atores (humanos e não humanos) do capitalismo financeiro atual que é exacerbado pela pandemia.

Nesse contexto, destacam-se os aeroportos e os fluxos aéreos, visto que representam hoje a maior mobilidade possível para seus passageiros, tomando a mobilidade no sentido que the dão Kleiman (2011) e Kauffman e Jemelin (2004): a medida da possibilidade de um indivíduo 
alcançar determinado ponto (deslocar-se) suplantando as fricções causadas por elementos externos, inclusos o próprio espaço-tempo, questões burocráticas, culturais e econômicas.

\section{Figura 2 - Cena aeroportuária comum e a mobilidade}

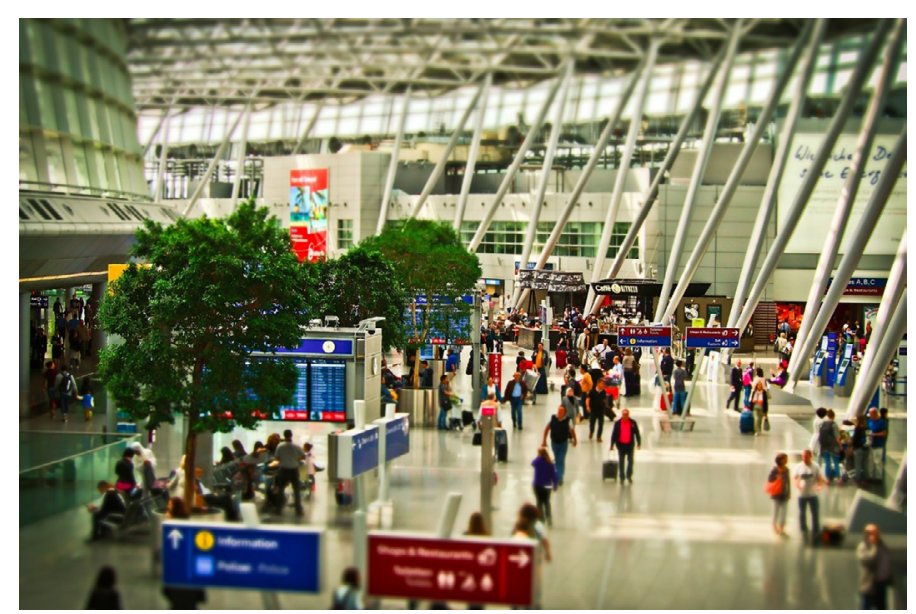

Foto de Michael Gaida, 2016. Disponibilizada por Pixabay, 2020.

Com isso, os aeroportos passam a ser as paisagens urbanas da mobilidade moderna por excelência, configurando-se, inclusive - os maiores -, com formas semelhantes à de pequenas cidades-globais. Para Adey (2011, p. 139, grifo do original, tradução nossa):

Como lugares e infraestruturas de vetores por excelência (Pascoe, 2001), ${ }^{5}$ aeroportos são também considerados entidades suficientemente fixas (Adey, 2006) ${ }^{6}$ ou nós (Crang, 2002) por onde passam massas e massas de coisas pela facilidade oferecida pelos voos. Mas eles são mais do que isso. Sendo mais do que representações de redes de linhas e vetores, aeroportos são feitos de vetores - eles são as próprias linhas de mobilidade que passam por eles e os criam. ${ }^{8}$

Esses espaços de hipermobilidade são perfeitos para a disseminação viral, visto que combinam nos mesmos estabelecimentos e espaços fechados viajantes de todo o mundo, durante 24 horas por dia. Alguns chegam, inclusive, a dormir ou passar 12 horas nos terminais, se alimentar $e$ se divertir. Ou seja, mais do que mediadores de fluxos, eles são feitos de fluxos. São vetores que carregam outros vetores, inclusive as infecções virais. Adey (2011, p. 140) apresenta um exemplo da atuação de aeroportos como condutores de vetores, apontando o efeito de ameaças como a Sars. No Mapa 5, podemos ver como a disseminação da Covid-19 pelo Brasil se relaciona com o fluxo dominante de passageiros por meio aéreo, identificado pelo IBGE (2013) em 2010.

5 PASCOE, D. Airspaces. London: Reaktion, 2001.

6 ADEY, P. Airports and Air-mindedness: spacing, timing and using Liverpool Airport 1929-1939. Social E Cultural Geography, London, v. 7, n. 3, p. 343-363, 2006.

7 CRANG, M. Between places: producing hubs, flows, and networks. Environment and Planning A, London, v. 34, n. 4, p. 569-574, 2002.

8 "As sites and infrastructures of vectors par excellence (Pascoe, 2001), airports are also interpreted as considerably sunk and fixed entities (Adey, 2006) or nodes (Crang, 2002) through which masses and masses of things pass by way of the airport's facilitation of flight. But they are more than that. Being more-than representations of networks of lines and vectors, airports are made up of vectors - they are the lines of mobility that pass through them and that make them" (Adey, 2011, p. 139, grifo do original). 
É possível observar como os municípios localizados em aeroportos conectados à rede de fluxo aéreo dominante de passageiros (IBGE, 2013) recebem a doença muito antes que seus vizinhos, principalmente se olharmos para o interior do país. E assim, tão logo a recebem, também se tornam vetores de disseminação local. $\bigcirc$ efeito também é notório na Amazônia, onde a maioria dos deslocamentos intermunicipais é feito por meio aéreo ou aquaviário.

Outros pontos de disseminação contrastantes são as cidades de Crato e Juazeiro do Norte (CE), Mossoró (RN), Petrolina (PE), Juazeiro, Barreiras, Vitória da Conquista, Ilhéus e Itabuna (BA), Patos de Minas, Governador Valadares e Montes Claros (MG), municípios próximos a Ji-Paraná (RO), Rondonópolis e Sinop (MT), Dourados (MS), Foz do Iguaçu, Cascavel, Londrina e Maringá (PR), Chapecó e Navegantes (SC), Santa Maria e Erechim (RS), Araçatuba, São José do Rio Preto, Presidente Prudente e São Carlos (SP), Campos dos Goytacazes, Macaé, Rio das Ostras e Cabo Frio (RJ), Rio Verde e Jataí (GO), Imperatriz (MA), Redenção e Parauapebas (PA), Tabatinga, Santa Isabel do Rio Negro, Eirunepé e Barcelos (AM), Cruzeiro do Sul (AC). Essas foram algumas das cidades identificadas em posição relativa, afastada espacialmente das capitais dos estados, porém próximas a aeroportos da rede aérea dominante (IBGE, 2013), que exibiram uma contaminação mais acelerada no período analisado, o que sugere a influência da rede de transportes como vetor de disseminação.

que se pretende afirmar com isso é que um protocolo de contenção pandêmica emergencial precisa ter como primeira ação a paralisação de voos e o fechamento de aeroportos, não só internacionais, mas também nacionais, assim que a ameaça for detectada. Níveis de ação também podem ser estabelecidos, visto que paralisar os aeroportos de São Paulo, que são o destino do fluxo dominante de passageiros e cargas no Brasil, teria um efeito maior do que paralisar outros aeroportos do país, pois desarticularia toda a dinâmica de mobilidade nacional. Isso faria os estados e municípios ganharem tempo para agir, pensando numa política de contenção emergencial, como a construção de hospitais de campanha ou grandes hospitais de emergência, como feito pela China.

\section{Mapa 5 - Casos confirmados de Covid-19 no Brasil, por município, de 25 de fevereiro a 1 de junho de 2020, fluxo dominante de passageiros por meio aéreo e a infraestrutura de transportes}

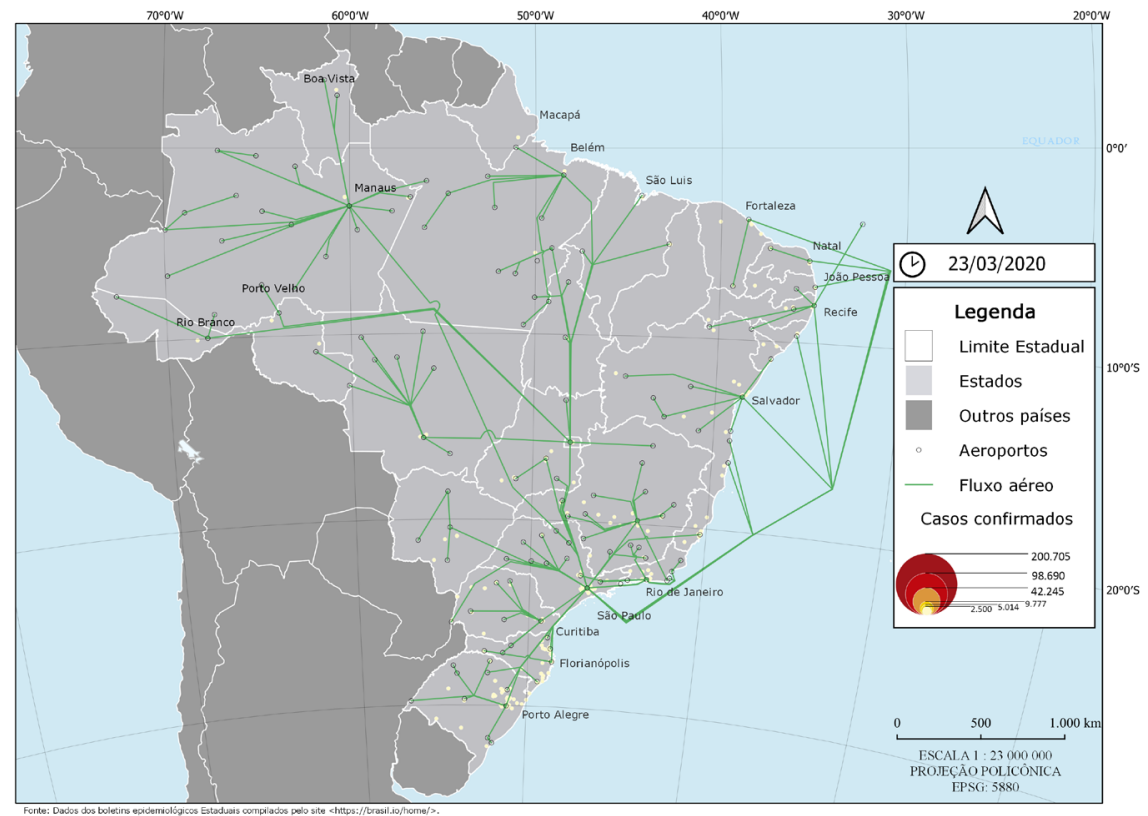



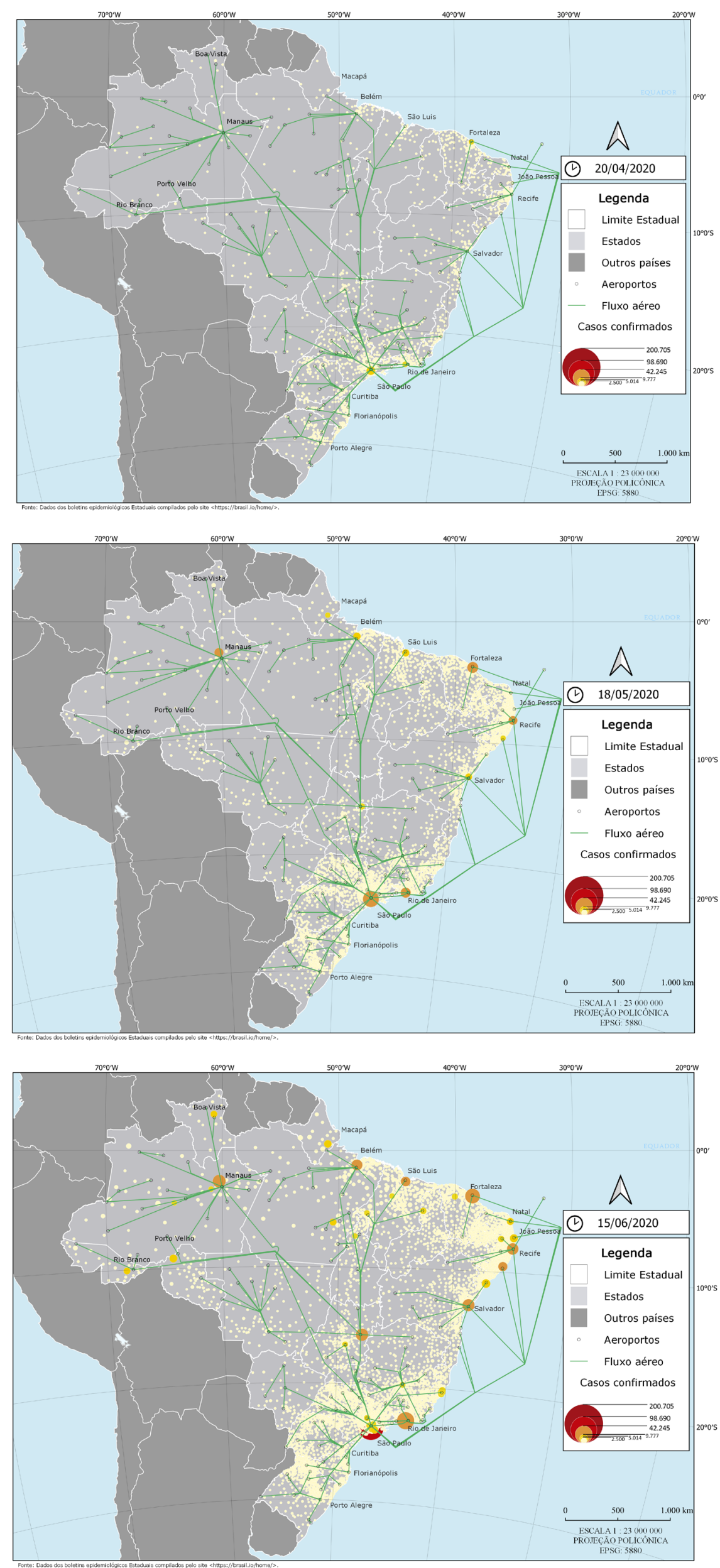

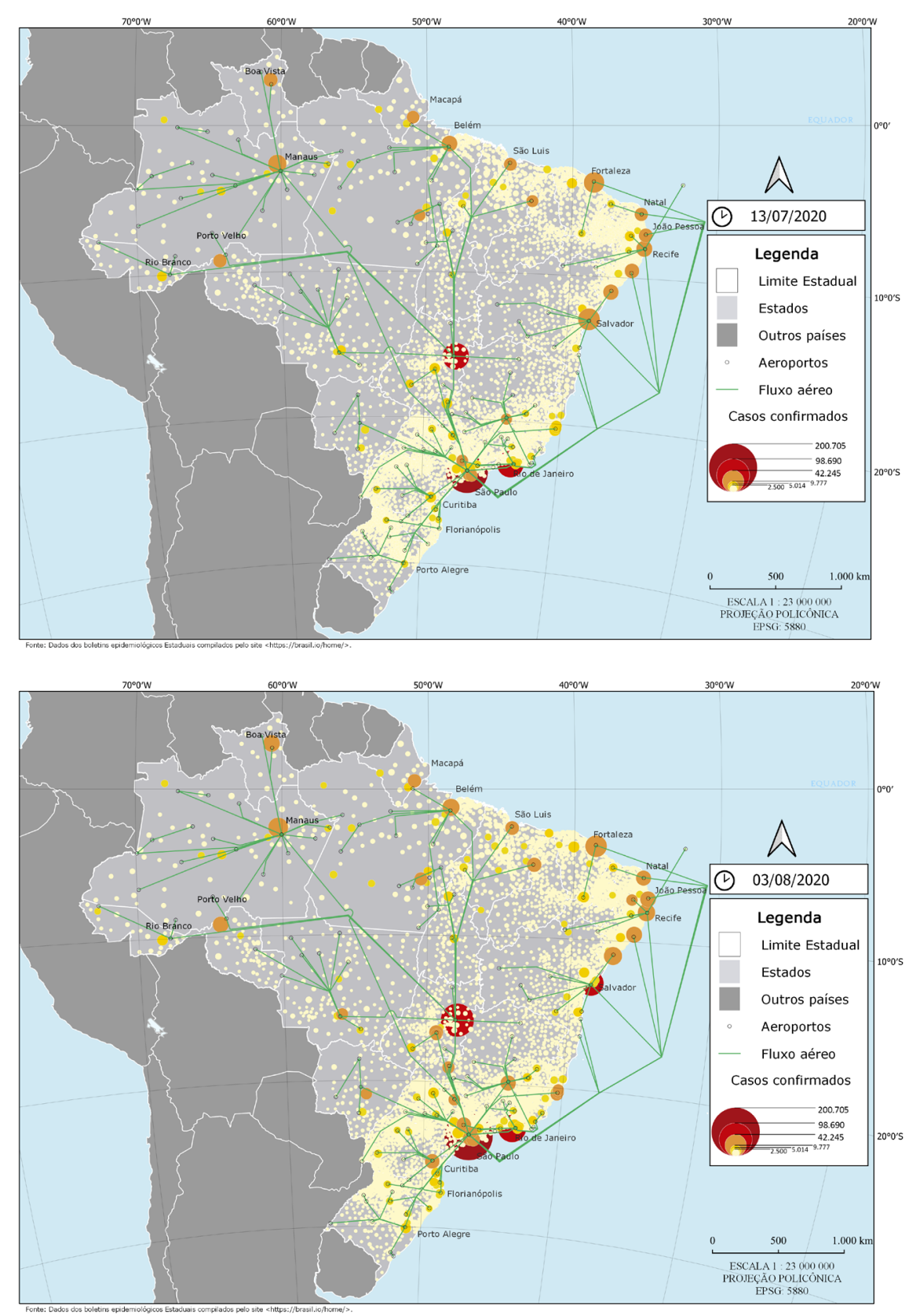

fonte: $O$ autor, 2020, com dados do IBGE (2013).

\section{Considerações finais}

A partir dos dados apresentados, é possível concluir que, quase dois meses após a notificação do primeiro caso de Covid-19 no Brasil, em 25/02/2020, a disseminação para o interior do país foi rápida, principalmente onde havia aeroportos que faziam parte da rede dominante do fluxo aéreo, ou seja, cuja principal ligação aeroviária é a cidade de São Paulo. Isso fica evidente se observarmos o interior da Bahia (Feira de Santana), do Paraná, do Mato Grosso, do Rio Grande do Norte (Mossoró) e de quase todas as capitais do Norte. Ressalta-se que o fluxo aéreo está intimamente ligado ao grau de mobilidade e à integração com os fluxos globais e com a atual configuração espacial do trabalho (Mattos, 2015; Harvey, 2011). Mas essa não é a única variável explicativa da rápida disseminação da doença. Vimos como diferentes políticas de contenção podem interferir 
nesse fenômeno e como a inobservância de planos e protocolos preestabelecidos pelo mundo ocidental foi um agravante, em contrapartida aos países orientais, já adequadamente munidos após epidemias anteriores como o ebola, a Mers e a Sars.

Pudemos observar como o processo de isolamento social na Argentina conteve a propagação rápida do vírus, que ficou um tanto restrito à província e à Cidade Autônoma de Buenos Aires. Porém, a partir de junho de 2020, por conta das necessidades econômicas da população e da pressão exercida pelas elites e por grupos econômicos, um afrouxamento desse isolamento fez aumentar o número de focos de disseminação no interior do país. Para estudos posteriores, pretendo estender a organização desses dados para verificar o fenômeno cartograficamente. Já no Brasil, por conta da não adoção de medidas iniciais de contenção, a difusão da doença pelo interior do país foi rápida, atingindo os principais aeroportos que tinham ligação com São Paulo pelo fluxo dominante de passageiros aéreos, e a taxa de contaminação seguiu um padrão relativamente linear e se mantém alta até o momento.

Concluímos pela eficácia das políticas públicas de enfrentamento do vírus aplicadas por países orientais, notadamente China e Cingapura, porém de formas diferentes. $\bigcirc$ primeiro com uma política de contenção emergencial, por meio de isolamento social severo, testagem e construção de hospitais, que resultou na estabilização do número de casos após um início fulminante, enquanto o segundo país adotou uma política de longo prazo, com a criação de clínicas especializadas de atenção básica (as PHPC). Essa política resultou numa taxa de contaminação que se refletiu numa curva suave e estabilizou em patamares relativamente baixos. Questionamos a razão pela qual os países ocidentais não valorizam políticas públicas voltadas ao controle de pandemias ou fomentam a adoção de protocolos conjuntos de enfrentamento a infecções virais, considerando que isso advém de um pensamento ocidentalista que não deu a devida importância às últimas grandes epidemias, possivelmente pelo fato de estas terem ficado restritas aos países do Oriente e à África.

Sobre as possíveis consequências que a sociedade pode tirar desta pandemia, entre as eventualmente benéficas, ressaltam-se as destacadas por Slavoj Žižek, de que não é possível enfrentá-la sem a cooperação global entre países e seres humanos:

[...] talvez outro vírus ideológico, muito mais benéfico, se espalhe e nos contagie: o vírus do pensamento em termos de uma sociedade alternativa, uma sociedade para além do Estado-nação, uma sociedade que se atualiza sob a forma de solidariedade e cooperação global (ŽZŽ̌EK, 2020, p. 43).

Concluindo, consideramos que, no Brasil, os protocolos de contenção pandêmica para futuras ameaças desse tipo deverão incluir, inicialmente, o fechamento dos aeroportos centrais do fluxo dominante de passageiros (Mapa 5) - atualmente São Paulo-SP, de acordo com o IBGE (2013) -, pois isso daria tempo para os municípios menores formularem suas políticas emergenciais de contenção. Destacamos, porém, que a política pública continuada adotada por Cingapura com as PHPC se mostrou o meio mais eficaz de proteção, comparado aos demais países analisados, apesar de talvez não ser o mais econômico. Para futuras pesquisas, recomenda-se a avaliação do custo-benefício de implantação dessas duas formas alternativas de política 
pública, para definir qual seria a mais apropriada para o Brasil. Ressalta-se ainda, até o momento da organização dos dados desta pesquisa, a falta de informações detalhadas num painel compilado por província como um grande dificultador das pesquisas em escala continental, visto que a compilação desses dados tem de ser feita manualmente. Um problema de escala mundial como esse demanda também ações conjuntas, e a falta de dados compilados em escala adequada pode implicar um grande atraso nas ações e prejudicar sua eficácia.

\section{Referências}

ADEY, P. Airports: Terminal/Vector. In: CRESSWELL, T.; MERRIMAN, P. Geographies of mobilities: practices, spaces, subjects. Farnham, GB/Burlington, VT: Ashgate, 2011. p. 137-150.

ARGENTINA é mais eficiente contra a Covid-19 do que o Brasil. Estado de Minas, Belo Horizonte, 15 abr. 2020. Internacional. Disponível em: https://www.em.com.br/app/ noticia/internacional/2020/04/15/interna_internacional, 1138645/argentina-e-mais-eficiente-contra-a-covid-19-do-que-o-brasil.shtml. Acesso em 24 nov. 2020.

BADIOU, A. Sobre a situação epidêmica. In: DAVIS, M. et al.: Coronavírus e a luta de classes. Brasil: Terra Sem Amos, 2020. p. 35-42.

BAUMAN, Z. Globalization: the human consequences. Cambridge, GB: Polity, 1998.

BIHR, A. França: pela socialização do aparato de saúde. In: DAVIS, M. et al.: Coronavírus e a luta de classes. Brasil: Terra Sem Amos, 2020. p. 25-30.

BRASIL.IO. Especial Covid-19: dados por município. [s.d.]. Disponível em: https://brasil.io/ covid19/. 1 base de dados. Acesso em: 21 abr. 2020.

CANDIDO, D. S.; CLARO, I. M.; JESUS, J. G.; SOUZA, W. M.; FARIA, N. R. Evolution and epidemic spread of Sars-Cov-2 in Brazil. Science, v. 369, n. 6508, p. 1255-1260, 2020. doi: https://doi.org/10.1126/science.abd2161.

CARGA chinesa com 600 respiradores artificiais é retida nos EUA e não será enviada ao Brasil. O Globo, 3 abr. 2020. Disponível em: https://oglobo.globo.com/sociedade/ carga-chinesa-com-600-respiradores-artificiais-retida-nos-eua-nao-sera-enviada-ao-brasil-24349142. Acesso em: 24 nov. 2020.

CARMO, M. Covid-19: como a Argentina se tornou um dos cinco países com mais casos do mundo. BBC News Brasil, Buenos Aires, 16 out. 2020. Disponível em: https:// www.bbc.com/portuguese/internacional-54576548. Acesso em: 24 nov. 2020.

COSTA, E. M.; COSTA, N. A pandemia Covid-19 em Portugal continental: uma análise geográfica da evolução verificada nos meses de março e abril. Hygeia - Revista Brasileira de Geografia Médica e da Saúde, Dossiê Covid-19, p. 72-79, jun. 2020. Edição Especial. doi: https://doi.org/10.14393/Hygeia0054396.

CUBA decide deixar programa Mais Médicos no Brasil e cita declarações "ameaçadoras" de Bolsonaro. G1, 14 nov. 2018. Mundo. Disponível em: https://gl.globo.com/ 
mundo/noticia/2018/11/14/cuba-decide-deixar-programa-mais-medicos-no-brasil. ghtml. Acesso em: 24 nov. 2020.

DAVIS, M. A crise do coronavírus é um monstro alimentado pelo capitalismo. In: DAVIS, M. et al.: Coronavírus e a luta de classes. Brasil: Terra Sem Amos, 2020. p. 5-12.

DÓRIA nega que tenha decretado lockdown em São Paulo. G1, São Paulo, 21 maio 2020. Disponível em: https://gl.globo.com/sp/sao-paulo/noticia/2020/05/21/doria-nega-que-tenha-decretado-lockdown-em-sao-paulo.ghtml. Acesso em: 24 nov. 2020.

EQUADOR decreta toque de recolher para conter coronavírus. R7, Rio de Janeiro, 17 mar. 2020. Disponível em: https://noticias.r7.com/internacional/equador-decreta-toque-de-recolher-para-conter-coronavirus-17032020. Acesso em: 24 nov. 2020.

HADFIELD, J.; MEGILL, C.; BELL, S.M.; HUDDLESTON, J.; POTTER, B.; CALLENDER, C.; SAGULENKO, P.; BEDFORD, T.; NEHER, R. A. Nextstrain: real-time tracking of pathogen evolution. Bioinformatics, v. 34, n. 23, p. 4121-4123, 2018. doi: https://doi.org/10.1093/bioinformatics/bty407.

HARVEY, D. Política anticapitalista em tempos de Covid-19. In: DAVIS, M. et al.: Coronavírus e a luta de classes. Brasil: Terra Sem Amos, 2020. p. 13-24.

HARVEY, D. O enigma do capital. São Paulo: Boitempo, 2011.

IBGE. INSTITUTO BRASILEIRO DE GEOGRAFIA E ESTATÍSTICA. Acesso e uso de dados geoespaciais. Rio de Janeiro: IBGE/CCAR, 2019.

IBGE. INSTITUTO BRASILEIRO DE GEOGRAFIA E ESTATÍSTICA. Ligações aéreas: 2010. Rio de Janeiro: IBGE/CGEO, 2013.

JONES, A. A volta do coronavírus a Cingapura, país que era "exemplo" no combate à doença. BBC News, 12 abr. 2020. Disponível em: https://www.bbc.com/portuguese/ internacional-52262728. Acesso em: 24 nov. 2020.

KAUFFMAN, V.; JEMELIN, C. La motilité, une forme de capital permettant d'éviter les irréversibilités socio-spatiales? In: COLLOQUE DE GÉOGRAPHIE SOCIALE "ESPACES ET SOCIETES AUJOURD' HUI”, 21 out. 2004, Rennes. Annales... Rennes, 2004.

KLEIMAN, M. Transportes e mobilidade e seu contexto na América Latina. Estudos e Debates, Rio de Janeiro: UFRJ, n. 61, p. 1-10, 2011.

KUGUYO, O.; KENGNE, A. P.; DANDARA, C. Singapore Covid-19 Pandemic response as a successful model framework for low-resource Health Care Settings in Africa? OMICS - A Journal of Integrative Biology, v. 24, n. 8, p. 470-478, 2020. doi: https://doi.org/10.1089/omi.2020.0077.

MARTIN, M. Como um vírus mortal abalou a economia asiática nos anos 2000. Deutsche Welle, 23 jan. 2020. Disponível em: https://p.dw.com/p/3WedY. Acesso em: 24 nov. 2020. Economia. 
MOREIRA, W. SuperVia vai diminuir o número de viagens dos trens a partir de 5 de novembro.

Diário do Transporte, 2 nov. 2020. Disponível em: https://diariodotransporte.com. br/2020/11/02/supervia-vai-diminuir-o-numero-de-viagens-dos-trens-a-partir-de-5-de-novembro/. Acesso em: 24 nov. 2020.

OLIVEIRA, J. R. Covid-19, vacinas e a licença compulsória de patentes. OAB, Espírito Santo, 1 jun. 2020. Disponível em: https://www.oabes.org.br/artigos/covid-19vacinas-e-a-licenca-compulsoria-de-patentes-58.html. Acesso em: 24 nov. 2020.

OLIVEIRA, M.; MELLO, I. Saiba em que estados e cidades já foi decretado o lockdown no Brasil. UOL, São Paulo, 9 maio 2020. Disponível em: https://noticias.uol.com.br/saude/ultimas-noticias/redacao/2020/05/09/saiba-onde-ja-foi-decretado-o-lockdown-no-brasil.htm. Acesso em: 24 nov. 2020.

OMS. ORGANIZAÇÃO MUNDIAL DA SAÚDE. Joint WHO-China Study: 14 January - 10 February 2021. WHO-convened global study of origins of Sars-Cov-2: China Part. Genebra: WHO, 2021.

SANTOS, M. Por uma outra globalização: do pensamento único à consciência universal. Rio de Janeiro: Record, 2000.

SMINK, V. "Estamos exaustos": o efeito da quarentena mais longa do mundo sobre os argentinos. BBC News Mundo, Argentina, 24 ago. 2020. Disponível em: https://www.bbc. com/portuguese/internacional-53870868. Acesso em: 24 nov. 2020.

SOUZA, C. Políticas públicas: uma revisão de literatura. Sociologia, Porto Alegre, v. 8, n. 16, p. 20-45, jul./dez. 2006.

WORLDOMETER. Covid-19 Coronavirus pandemic: reported cases and deaths by Country, Territory, or Conveyance. 1 base de dados. Disponível em: https://www.worldometers.info/ coronavirus/\#countries. Acesso em: 24 nov. 2020.

ŽIŽEK, S. Um golpe como "Kill Bill" no capitalismo. In: DAVIS, M. et al.: Coronavírus e a luta de classes. Brasil: Terra Sem Amos, 2020. p. 43-47.

Recebido em: 25 nov. 2020 Aprovado em: 6 out. 2021 